\title{
Preliminary investigation on the use of artificial substrates to favor Tritia mutabilis (Linnaeus, 1758) spawning in Central Adriatic Sea: a possible contribution to stock maintenance
}

\author{
Riccardo CAPRIOLI* and Carla GIANSANTE \\ Laboratory for Hygiene, Biology and Environmental Toxicology, Istituto \\ Zooprofilattico Sperimentale dell'Abruzzo e del Molise 'G. Caporale', Via Campo \\ Boario 64100 Teramo, Italy
}

*Corresponding author, e-mail: r.caprioli@izs.it

\begin{abstract}
Tritia mutabilis, formerly classified as Nassarius mutabilis, represents an important but declining resource for small scale fishery in the central Adriatic Sea, likely due to overfishing. A preliminary investigation on the use of artificial substrates to favour its spawning was carried out in a coastal area off the Abruzzi region, central Italy. Between May and June 2015, five groups of six pyramid structures made of a steel frame covered by plastic net, with a $0.5 \mathrm{~m}^{2}$ surface available for deposition, were placed on sandy bottoms at about 0.5 nautical miles from the coast and at sea depths ranging from $5.5 \mathrm{~m}$ to $7.5 \mathrm{~m}$. A density of T. mutabilis egg capsules $>1$ per $100 \mathrm{~cm}^{2}$ was observed in two of the pyramid groups. The number of embryos present in each capsule ranged from 8 to 22 (mean number: 14). At the end of the study, almost all the capsules presented an apical opening and were empty, thus indicating successful hatching and larval release. This preliminary investigation shows that the natural deposition of T. mutabilis egg capsules can be facilitated by placing artificial substrates on sandy bottoms and it is conceivable that their use would contribute to maintain sustainable stocks of this species.
\end{abstract}

Key words: Tritia mutabilis, Nassarius mutabilis, artificial substrates, spawning, Adriatic Sea

\section{INTRODUCTION}

The changeable nassa Nassarius mutabilis (Gastropoda, Nassaridae) (Fig. 1a), recently classified as Tritia mutabilis (GALINDO et al., 2016; MARSHALL \& GOFAS, 2016), is a common nassarid found in sandy or muddy bottoms throughout the Mediterranean coastal waters, at depths ranging between 2 and $15 \mathrm{~m}$ (PICCINETTI \& PICCINETTI MANFRIN, 1998; GRATI et al., 2010; POLIDORI et al., 2015). It has separate sexes and reproduction occurs between late winter and spring (CESPUGLIO et al., 1999). Fertilization is internal and spheroidal embryos are deposed within benthic, transparent egg capsules attached to hard substrates (SODERI, 1975; D'ASARO, 1993; POLIDORI et al., 2015). Planktotrophic larvae emerge from the capsules and require approximately two months to complete metamorphosis and settlement. The life cycle is completed within two to three years (CESPUGLIO et al., 1999; RIEDL, 1991).

Small-scale T. mutabilis fishery is a common practice and an important resource along the central and northern Adriatic Sea Italian coast (PICCINETTI \& PICCINETTI MANFRIN, 1998; BALDUCCI et al., 2006; GRATI et al., 2010; POLIDORI et al., 


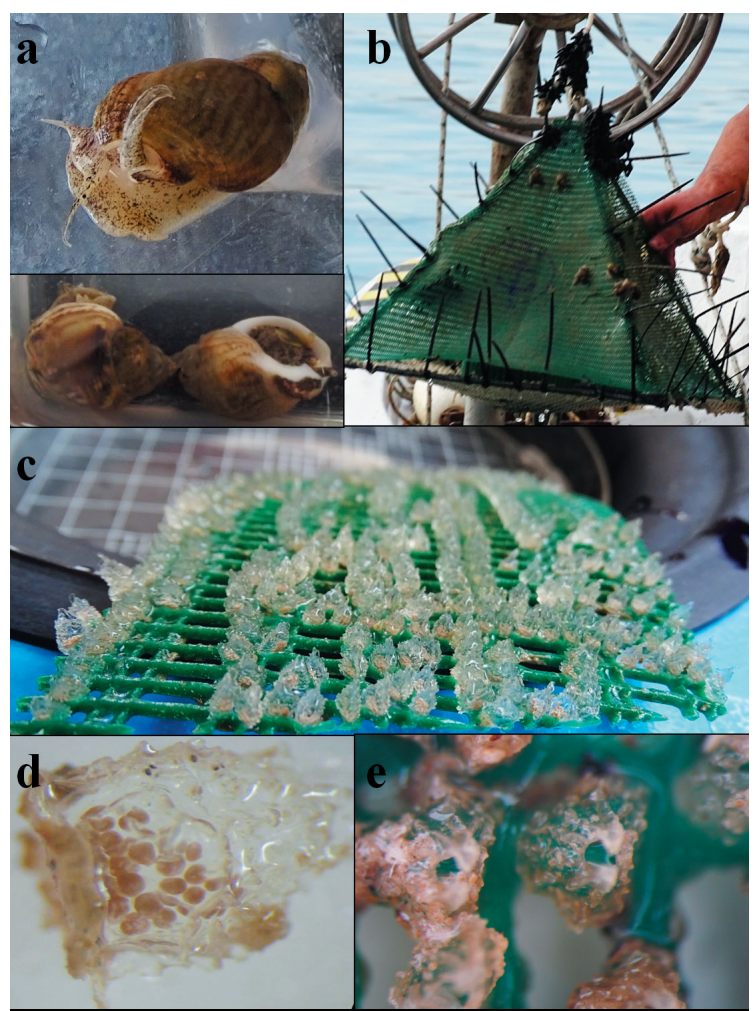

Fig. 1. a) Photographs of Tritia mutabilis specimens, b) Pyramid used as artificial substrate for T. mutabilis egg capsule deposition, c) T. mutabilis egg capsules laid on a pre-cut plastic net square on the side wall of a pyramid artificial substrate, d) egg capsule detached from the artificial substrate and observed at the stereomicroscope. Numerous embryos can be seen inside the capsule, e) hatched egg capsule presenting an apical opening

2015). The consumption of this species is popular among the local population and, in winter time, it represents an important source of income for small scale fishery in the Adriatic Sea, accounting for $19.6 \%$ of the total catch and $13.0 \%$ of the total revenues in the year 2011 (IREPA, 2012). Fishing activity is conducted in the period between early fall and late spring using small cone-shaped basket traps baited with dead fish (GRATI et al., 2010), and it is regulated in terms of fishing periods, maximum daily catch amount, minimum landing size (20 mm shell height), and sanitary classification of the catching sea areas in accordance with Regulation 854/2004 / EC (EUROPEAN COMMISSION, 2004). Despite such a detailed regulatory framework, T. mutabilis resource has undergone a constant decrease in the last decade, probably due to an excessive fishing effort (PICCINETTI \& PICCINETTI MANFRIN, 1998; BALDUCCI et al., 2006; FABI et al., 2006; GRATI et al., 2010; POLIDORI et al., 2015). As a matter of fact, the annual catch of T. mutabilis passed from 1.579 tons in 2010 to 2.220 tons in 2015 (http://www.ismea.it/flex/cm/pages/ServeBLOB.php/L/IT/IDPagina/9709\#MenuV).

A further threat for this species could be represented by predation on encapsulated larvae by crabs or hermit crabs, as reported for the gastropod Ilyanassa obsoleta (BRENCHLEY, 1982), and by the negative effects on the reproduction caused by the imposex phenomenon, recently reported by LAHBIB et al. (2013) in a T. mutabilis population from the Lagoon of Bizerta (northern Tunisia). Imposex is associated with water pollution due to antifouling paints (FENT, 1996) and consists on a superimposition of male sex organs onto female gastropods, which causes an alteration of the gametogenesis, with cessation of oocyte maturation and development of semen tubules with early stages of spermatogenesis (GIBBS et al., 1988).

To achieve an enhancement of T. mutabilis stocks in central and northern Adriatic Sea, POLIDORI et al. (2015) recently proposed a revision of the current management measures, suggesting a shortening of the fishing season and a revision of the minimum landing size. Another possible approach to contribute to maintenance and enhancement of T. mutabilis stocks could be the adoption of measures to support the reproduction of the species in the area. T. mutabilis attaches its egg capsules to solid substrates (SODERI, 1975; POLIDORI et al., 2015), which are not frequent on the fine sandy bottoms that characterize most of the central Adriatic Sea coast of Italy. In these areas, T. mutabilis egg capsules are commonly found attached to the sidewalls of the basket traps and to other submerged gear used for small-scale fishing, laid on sandy bottoms during the spawning season. Moreover, an attempt to provide artificial substrates to favor egg capsules deposition was recently carried out with encouraging results by fishermen in the Marche region, central Italy (http://www.blumarineservice.it/images/download/brochure_sea_ 
snail_it.pdf). These observations prompted us to conduct a preliminary experimental investigation to evaluate the use of artificial substrates designed to optimize T. mutabilis egg capsules deposition in sandy sea bottoms.

\section{MATERIAL AND METHODS}

The study was carried out in a Central Adriatic Sea area facing the Abruzzi region, nearby the port of Ortona (Fig. 2). The artificial substrates used for egg capsule deposition were pyramid structures with a square base, measuring $50 \mathrm{~cm}$ in width and $40 \mathrm{~cm}$ in height, and made of a steel frame $(\varnothing=8 \mathrm{~mm})$ covered by net (Fig. $1 \mathrm{~b})$. The pyramid base was covered with a high strength nylon net with a mesh size of $20 \mathrm{~mm}$, while the four side walls were covered with a plastic net with a mesh size of $3 \mathrm{~mm}$. The lateral surface available for deposition in each structure was about $0.5 \mathrm{~m}^{2}$. On each pyramid, squares with 50 $\mathrm{mm}$ side were pre-cut in the plastic net to make them easily removable from the structure, thus allowing the enumeration of the embryos present in the capsules. A $1 \mathrm{~kg}$ weight was placed in the center of the pyramid base to provide stability and avoid overturning. The structures were realized by Blu Marine Service Soc. Coop. (San Benedetto del Tronto, AP, Italy), using non-toxic

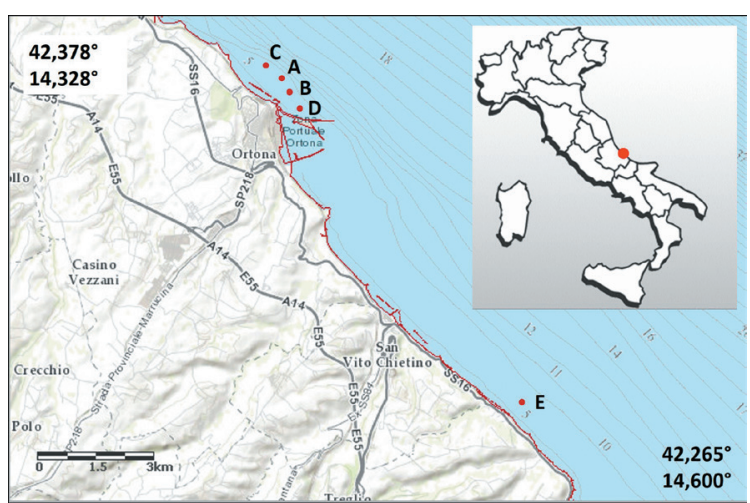

Fig. 2. Map of the study area in the Central Adriatic Sea, nearby the port of Ortona, Abruzzi region, Italy. The dots indicate the position of the five groups of artificial substrates deployed for the study

materials.

A total of 30 pyramids, assembled in five groups (from A to E) constituted by six units, were lowered into the sea by professional fisherman between 12 and 13 May 2015, at a distance from the coast ranging from 0.32 to 0.64 nautical miles, at a sea depth ranging from $5.5 \mathrm{~m}$ to $7.5 \mathrm{~m}$ (Fig. 2). The pyramid groups were kept in position on the sandy seabed with anchors and identified on the surface by a signal. A monitoring visit was carried out after about 15 days and the substrates were definitively removed from the sea and examined after about one month

Table 1. Presence of Tritia mutabilis egg capsules on pyramid artificial substrates placed on sandy bottoms in the central Adriatic Sea. $N D=$ Not determined

\begin{tabular}{|l|l|l|l|l|l|l|}
\hline $\begin{array}{l}\text { Artificial } \\
\text { substrate } \\
\text { group }\end{array}$ & $\begin{array}{l}\text { Depth } \\
(\mathrm{m})\end{array}$ & $\begin{array}{l}\text { Observation } \\
\text { date }\end{array}$ & $\begin{array}{l}\text { Mean pyramid } \\
\text { surface covered by } \\
\text { egg capsules (\%) }\end{array}$ & $\begin{array}{l}\text { Mean } \\
\text { number of } \\
\text { egg capsules } \\
\text { per } 100 \mathrm{~cm}^{2}\end{array}$ & $\begin{array}{l}\text { Mean number } \\
\text { of embryos per } \\
\text { capsule }\end{array}$ & $\begin{array}{l}\text { Proportion } \\
\text { of hatched } \\
\text { capsules (\%) }\end{array}$ \\
\hline A & 6.3 & 26 May 2015 & $<1$ & $<1$ & ND & ND \\
\cline { 2 - 7 } & 5.6 & 15 June 2015 & $<1$ & $<1$ & 0 & 100 \\
\hline \multirow{2}{*}{ B } & 26 May 2015 & $<1$ & $<1$ & ND & ND \\
\hline C & 5.5 & 26 June 2015 & $<1$ & $<1$ & 0 & 100 \\
\cline { 2 - 7 } & & 15 June 2015 2015 & 41.2 & $957 \pm 156$ & $15.0 \pm 1.1$ & 0 \\
\hline D & 5.5 & 29 May 2015 & $<1$ & $1,167 \pm 114$ & $12.8 \pm 1.8$ & 87 \\
\cline { 2 - 7 } & & 15 June 2015 & $<1$ & $<1$ & ND & ND \\
\hline E & 7.5 & 29 May 2015 & 3.0 & $<1$ & 0 & 100 \\
\cline { 2 - 7 } & & 16 June 2015 & $<1$ & $<1$ & 0 & 0 \\
\hline
\end{tabular}


(Table 1). Water temperature and salinity were measured at the beginning and at the end of the study, as well as at the monitoring visit, using a multi-parametric probe HI9828 (Hanna Instruments, Ronchi di Campanile, Padua, Italy). During the visit and at the end of the study the presence of egg capsules was assessed and the side walls of the pyramids were photographed using a digital camera with a graduated reference. T. mutabilis egg capsules were identified through microscope observation, on the basis of their morphology (SODERI, 1975; D'ASARO, 1993). In particular, they were distinguished from the capsules of Nassarius reticulatus (D'ASARO, 1993; ZUPO \& PATTI, 2009) by the presence of complex lateral ridges and spines and by the relatively low number of embryos per capsule. The percentage of available pyramid surface covered with egg capsules was estimated by analyzing the calibrated digital images using the ImageJ software (Research Services Branch, National Institute of Mental Health, Bethesda, Maryland, USA). The pre-cut squares were removed from the side wall plastic nets and transferred to the laboratory in refrigerated water containers to estimate the density of the egg capsules, expressed as their number per 100 $\mathrm{cm}^{2}$. Egg capsules were removed with a scalpel and observed with a stereomicroscope Wild M3 (Leica Microsystems, Milan, Italy) to determine the number of embryos present. The percentage of hatching egg capsules was also estimated. The relation between egg capsule size (height) and number of embryos per capsule was evaluated by linear regression analysis using the statistical software PAST 3.14 (HAMMER et al., 2001)

\section{RESULTS}

During the study period, the water temperature at the surface ranged from $19{ }^{\circ} \mathrm{C}$ at the beginning of the study to $25{ }^{\circ} \mathrm{C}$ at its end, and that at the bottom from $19{ }^{\circ} \mathrm{C}$ to $22^{\circ} \mathrm{C}$. Salinity ranged from 31.8 and $34.2 \mathrm{gL}^{-1}$ at the surface and from 32.4 to $34.3 \mathrm{gL}^{-1}$ at the bottom. At the monitoring visit, carried out between 26 and 29 May 2015, a density of T. mutabilis egg capsules $>1$ per $100 \mathrm{~cm}^{2}$ was observed in two of the five

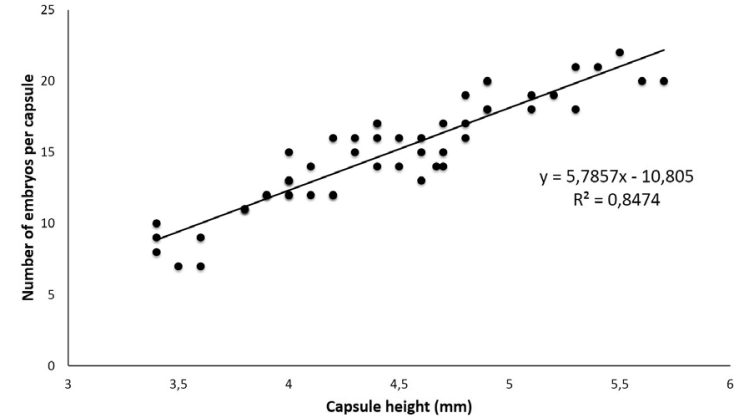

Fig. 3. Correlation between number of embryos and egg capsule size in Tritia mutabilis

groups of pyramid substrates (Table 1). The mean numbers of capsules per $100 \mathrm{~cm}^{2}$ of substrate surface were 957 and 60 for the group C and group E pyramids, respectively. Only a few egg capsules were observed on the side walls of the other pyramid groups, preferentially located on the corners. Numerous cuttlefish (Sepia officinalis) and black goby (Gobius niger) eggs were also found on the side walls of all the pyramids.

T. mutabilis egg capsules (Fig. 1c) appeared as sculptured, almond-shaped structures with a mean height of $4.7 \pm 0.7 \mathrm{~mm}$, a mean basal length of $3.4 \pm 0.1 \mathrm{~mm}$, and complex lateral ridges (D'ASARO, 1993). They stick firmly to the plastic net, had a rubbery texture, rather resistant to compression and cuts, and could be removed only by using a sharp scalpel blade. At the cut surface, the capsule membrane was smooth and transparent, allowing the observation and enumeration of the embryos (Fig. 1d). None of the observed egg capsules was hatched. The number of embryos present in each capsule was significantly related with its size $(\mathrm{p}<$ $0.001, r^{2}=0,8474, n=54$, Fig. 3 ), and ranged from a minimum of 7 to a maximum of 22 embryos for the largest capsules (mean number: 14). The embryos usually presented a uniform light brown color and a spherical or trapezoidal shape, but sometime elongated, rod-shaped forms were observed. In some capsules, the embryos showed a disc-shaped swelling with a light grey color at one end, probably indicating a different development stage.

The artificial substrates were removed on 15 and 16 June 2015, at the end of the study, and an egg capsule density $>1$ per $100 \mathrm{~cm}^{2}$ was 
observed only in group C pyramids (Table 1). The mean number of capsules was 1,167 per $100 \mathrm{~cm}^{2}$, with a $22 \%$ increase with respect to the previous monitoring visit. Most egg capsules $(87 \%)$ presented an apical opening and were empty (Fig. 1e), thus indicating successful egg capsule hatching and larval release. Most of the egg capsules observed on the group E pyramids at the first monitoring visit were no longer present, and the few remaining along the pyramid corners were empty, as well as the few scattered capsules observed on the other pyramid groups.

\section{DISCUSSION}

The results of this preliminary investigation indicate that the natural deposition of T. mutabilis egg capsules can be facilitated by placing artificial substrates on sandy bottoms, even though the number of egg capsules found on three of the five groups of pyramid substrates deployed for the study was very low. For the other two groups of pyramids (C and $\mathrm{E}$ ) the surface covered with egg capsules corresponded respectively to about $40 \%$ and $3 \%$ of the total available surface. These figures are lower than those previously observed by fishermen in the coastal waters of the Marche region, about 100 $\mathrm{km}$ north of our study area, using artificial substrates similar to the pyramids employed in this study (http://www.blumarineservice.it/images/ download/brochure_sea_snail_it.pdf). That attempt was conducted leaving the substrates at sea between January and June 2013, and abundant amounts of egg capsules on the pyramid surfaces were reported. This suggests that the low yield obtained in our study was likely due to a late placement of the artificial substrates at sea, due to technical problems with their availability. Indeed, the substrates were placed at sea in midMay, when the water temperature at both the surface and the bottom was already $18-19{ }^{\circ} \mathrm{C}$. In the Nassariidae family, egg capsule deposition is usually timed according to seasonal changes of temperature and salinity (SCHELTEMA, 1961, BARROSO \& MOREIRA, 1998; CHAN \& MORTON, 2005). For Nassarius obsoletus, an optimal temperature of $16^{\circ} \mathrm{C}$ for egg capsule laying has been reported
(SCHELTEMA, 1961), while BARROSO \& MOREIRA (1998) observed that the release of gametes by $N$. reticulatus in Portuguese coastal waters was associated with the increase of water temperature above $11^{\circ} \mathrm{C}$, at the end of the winter. In our study area, the water temperature usually increases rapidly from $10-11^{\circ} \mathrm{C}$ at the beginning of March to $15-16{ }^{\circ} \mathrm{C}$ around middle April, and T. mutabilis spawning probably begins in that period. Accordingly, the local fisherman reported the presence of T. mutabilis egg capsules on submerged fishing gear mainly in April. Therefore, it is likely that our experimental study has been carried out when the spawning season was close to its end, as also suggested by the observation that almost all the egg capsules still present on the pyramids at the end of the study, in mid-June, were hatched. On the other hand, the deposition of egg capsules on our devices and the increase in their number on the group $\mathrm{C}$ pyramids observed between the monitoring visit and the end of the study indicate that spawning individuals were present until the end of May, which probably represents the limit of T. mutabilis spawning season in the study area.

Despite the socio-economic importance of the species and the detailed fishery regulatory framework, the reproductive biology of $T$. mutabilis has not been thoroughly described so far (SODERI, 1975; RIEDL, 1991; D'ASARO, 1993; PICCINETTI \& PICCINETTI MANFRIN, 1998; POLIDORI et al., 2015). In this respect, this study may contribute to a better knowledge of the spawning process of the species in the Adriatic Sea, because we observed a mean number of embryos per capsule (14, with a range varying from 7 to 22 embryos) that was higher than that (6-7 embryos for capsule) recorded in a study conducted in the laboratory (SODERI, 1975) and comparable with the number reported for specimens from the Tyrrhenian Sea (D'ASARO, 1993). A significant positive correlation between the number of embryos and the dimension of the capsule was also observed, and the egg capsule hatching time at $19{ }^{\circ} \mathrm{C}$ could be estimated around 15 days, since most of the recorded egg capsules hatched during the interval between the monitoring visit and the end of the study. 


\section{CONCLUSIONS}

The devices deployed in this study, pyramids made by a steel frame covered by a plastic net, proved to be an adequate artificial spawning substrate for T. mutabilis. Moreover, they are easy and economical to build, and the fishermen who participated in the project judged them easy to use. Indeed, they are relatively light and their use requires a limited workload, since they can be placed at sea at the beginning of T. mutabilis reproductive period and removed only at its end, or otherwise transferred to other areas selected for restocking before egg capsule hatching. In the central Adriatic Sea, the artificial spawning substrates should be kept at sea from mid-March to the end of May and their appropriate use could increase the spawning possibilities for $T$. mutabilis in sandy bottom areas where suitable natural substrates are scarce, thus contributing to maintain sustainable stocks of this species. Finally, the observation that other marine organisms, in particular cuttlefish and black goby, laid their eggs on the pyramids, indicates that these artificial substrates can also facilitate the reproduction of other species of interest to small-scale fishing, with the further added value of favoring biodiversity.

\section{ACKNOWLEDGMENTS}

This study was supported by a research grant from the Abruzzi Region: FEP 2007/2013 ASSE 3, MISURA 3.5 (Progetti/Operazioni Pilota Reg. Cen. 1198/2006 art. 41, par. 2, lett. b). The authors are grateful to the staff of Blu Marine Service Soc. Coop. for their technical support and to the fishermen involved in the project for their valuable assistance during the field work.

\section{REFERENCES}

BALDUCCI, G.M., H. OMICCIOLI, S. GIANNATTASIO, D. MINELLI, V. COLLEVECCHIO, M. VALLISNERI \& B. SABELLI. 2006. Studio sulla biologia e distribuzione di Nassarius mutabilis (L., 1758) (Gastropoda, Prosobranchia) nel compartimento marittimo di Pesaro per una corretta gestione della risorsa (Biology and distribution of Nassarius mutabilis (L., 1758) (Gastropoda, Prosobranchia) for a correct management at Pesaro's marine department. Biol. Mar. Medit., 13: 156-157.

BARROSO, C.M. \& M.H. MOREIRA. 1998. Reproductive cycle of Nassarius reticulatus in the Ria de Aveiro, Portugal: Implications for imposex studies. J. Mar. Biol. Assoc. UK, 78: 1233-1246.

BRENCHLEY, G.A. 1982. Predation on encapsulated larvae by adults: effects of introduced species on the gastropod Ilyanassa obsoleta. Mar. Ecol. Prog. Ser., 9: 255-262.

CESPUGLIO, G., C. PICCINETTI \& A. LONGINELLI. 1999. Oxygen and carbon isotope profiles from Nassa mutabilis shells (Gastropoda): accretion rates and biological behaviour. Mar. Biol., 135: 627-634.
CHAN, K. \& B. MORTON. 2005. The reproductive biology of Nassarius festivus (Powys, 1835) (Gastropoda: Nassariidae) in relation to seasonal changes in temperature and salinity in subtropical Hong Kong. Aquat. Ecol., 39 (2): 213-228.

D'ASARO, C.N. 1993. Gunnar Thorson's worldwide collection of Prosobranch egg capsules: Nassariidae. Ophelia, 38: 149-215.

EUROPEAN COMMISSION (EC) 2004. Regulation (EC) No 854/2004 of the European Parliament and of the Council of 29 April 2004 laying down specific rules for the organisation of official controls on products of animal origin intended for human consumption. Off J, L 139, 30/04/2004, 206-320.

FABI, G., F. GRATI, M. DE MAURO \& P. POLIDORI. 2006. Distribuzione spaziale e densità di Nassarius mutabilis (L.) e Nassarius reticularis (L.) nel compartimento marittimo di Ancona (Spatial distribution and density of Nassarius mutabilis (L.) and Nassarius reticulatus (L.) in the maritime department of Ancona). Biol. Mar. Medit., 13: 240-241.

FENT, K. 1996. Ecotoxicology of organotin compounds. Crit. Rev. Toxicol., 26: 1-117. 
GALINDO, L.A., N. PUILLANDRE, J. UTGE, P. LOZOUET, \& P. BOUCHET. 2016. The phylogeny and systematics of the Nassariidae revisited (Gastropoda, Buccinoidea). Mol. Phylogenet. Evol., 99: 337-353.

GIBBS, P.E., P.L. PASCOE \& G.R. BURT. 1988. Sex change in the female dog-whelk, Nucella lapillus, induced by tributyltin from antifouling paints. J. Mar. Biol. Assoc. UK, 68: 715-731.

GRATI, F., P. POLIDORI, G. SCARCELLA \& G. FABI. 2010. Estimation of basket trap selectivity for changeable nassa (Nassarius mutabilis) in the Adriatic Sea. Fish. Res., 101: 100-107.

HAMMER, Ø., D.A.T. HARPER, \& P. D. RYAN. 2001. PAST: Paleontological Statistics Software Package for Education and Data Analysis. Palaeontologia Electronica, 4 (1): 9 pp.

IREPA, 2012. Osservatorio economico sulle strutture produttive della pesca marittima in Italia 2011. Napoli: Edizioni Scientifiche Italiane, pp. 252. ISBN 978-88-495-2571-7

LAHBIB, Y., S. ABIDLI, \& N. TRIGUI EL MENIF. 2013. Description of imposex and butyltin burden in Nassarius mutabilis from the Lagoon of Bizerta (northern Tunisia). Russ. J. Mar. Biol., 39: 70-75.

MARSHALL, B. \& S. GOFAS. 2016. Nassarius mutabilis (Linnaeus, 1758). In: MolluscaBase (2016). Accessed through: World Register of Marine Species at: http:/www.marinespecies.org/aphia.php? $\mathrm{p}=$ taxdetails $\& \mathrm{id}=876840$. Accessed on 21 October 2017.
PICCINETTI, C. \& G. PICCINETTI-MANFRIN. 1998. Considerazioni per la gestione della pesca del lumachino, Nassarius mutabilis (Linnaeus, 1758) (Consideration for the management of Nassarius mutabilis fishery). Biol. Mar. Medit., 5: 355-361.

POLIDORI, P., F. GRATI, L. BOLOGNINI, F. DOMENICHETTI, G. SCARCELLA \& G. FABI. 2015. Towards a better management of Nassarius mutabilis (Linnaeus, 1758): biometric and biological integrative study. Acta Adriat., 56: 233-244.

RIEDL, R. 1991. Fauna e flora del Mediterraneo. Franco Muzzio Editore, Gruppo Editoriale Italiano S.r.1., Rome, Italy. ISBN13: 9788874132249, 776 pp.

SCHELTEMA, R.S. 1961. Metamorphosis of the veliger larvae of Nassarius obsoletus (Gastropoda) in response to bottom sediment. Biol. Bull. Mar. Biol. Lab., Woods Hole., 120: 92-109.

SODERI, A. 1975. Osservazioni relative a ovodeposizione di Sphaeronassa mutabilis (L.) (Gastropoda, Neogastropoda) in acquario (Observations on the oviposition of Sphaeronassa mutabilis (L.) (Gastropoda, Neogastropoda) in aquarium. Conchiglie., 11: 247-251.

ZUPO, V. \& F.P. PATTI. 2009. Laboratory spawning, larval development and metamorphosis of the marine snail Nassarius reticulatus (L.) (Caenogastropoda, Nassariidae). Invertebr. Reprod. Dev., 53: 23-31.

Received: 13 December 2016

Accepted: 23 October 2017 


\title{
Preliminarna istraživanja o uporabi umjetnih supstrata koji bi pogodovali mrijestu puža Tritia mutabilis (Linnaeus, 1758) na središnjem Jadranu: mogući doprinos održavanju stocka
}

\author{
Riccardo CAPRIOLI* i Carla GIANSANTE \\ *e-pošta: r.caprioli@izs.it
}

\begin{abstract}
SAŽETAK
Puž Tritia mutabilis, nekad klasificiran kao Nassarius mutabilis, predstavlja važan, ali opadajući resurs priobalnog ribolova u središnjem Jadranu, vjerojatno zbog pretjeranog izlova. Na obalnom području pokrajine Abruzzo (središnja Italija) provedena su preliminarna istraživanja o korištenju umjetnih supstrata koji pogoduju mrijestu T. mutabilis. U razdoblju od svibnja do lipnja 2015. godine, na pješčana dna udaljena oko 0,5 nautičkih milja od obale, postavljeno je pet grupa od šest piramidalnih konstrukcija izrađenih od čeličnog okvira prekrivenog plastičnom mrežom površine od $0,5 \mathrm{~m}^{2}$ na dubini od 5,5 do 7,5 metara.

Opažena je gustoća kapsule jajašaca T. mutabilis od $>1$ po $100 \mathrm{~cm}^{2} \mathrm{u}$ dvije piramidalne skupine. Broj embrija prisutnih u svakoj kapsuli kretao se od 8 do 22 (srednji broj: 14).

Na kraju istraživanja, gotovo sve kapsule imale su apeksni otvor i bile su prazne, što ukazuje na uspješno lučenje i otpuštanje larve.

Ovo preliminarno istraživanje pokazuje da se prirodno taloženje jajčanih kapsula T. mutabilis može olakšati stavljanjem umjetnih supstrata na pješčana dna, te je vjerojatno da bi njihova uporaba doprinijela održavanju zaliha ove vrste.
\end{abstract}

Ključne riječi: Tritia mutabilis, Nassarius mutabilis, umjetni supstrati, mriješćenje, Jadransko more 